\title{
Harapan Orang Tua dalam Mendidik Anak Usia Dini ${ }^{1}$
}

\author{
Radhiya Bustan ${ }^{1}$, Nurfadilah ${ }^{2}$, Nila Fitria ${ }^{3}$ \\ ${ }^{1}$ Program Studi Psikologi, ${ }^{2,3}$ Program Studi Pendidikan Anak Usia Dini, Fakultas Psikologi dan Pendidikan, \\ Universitas Al-Azhar Indonesia, Jl.Sisingamangaraja, Jakarta 12110
}

Penulis untuk Korespondensi/E-mail: radhiya_bustan@yahoo.com

Abstrak - Orang tua masa kini, terutama yang berada di kota besar semakin dihadapkan pada tantangan yang sulit dalam mengasuh dan mendidik anak karena orangtua tidak hanya menghadapi tantangan yang timbul seiring dengan perkembangan anak dalam setiap siklus kehidupannya (Carter \& McGoldrick dalam Craig,1986), tapi juga harus berjuang menghadapi kondisi politik, sosial dan ekonomi yang berpotensi besar melemahkan kemampuan mereka untuk memberikan dukungan yang tepat untuk anak-anak (Evans, Judith L, 2006). Para orangtua, khususnya orangtua yang memiliki anak usia dini memiliki banyak cara untuk mengoptimalkan peran pengasuhan mereka, salah satunya adalah dengan melibatkan asisten rumah tangga, baby sitter, ataupun dengan keluarga mereka yang lain. Akibatnya, hal ini juga mempengaruhi peran serta orangtua dalam pendidikan anak di dalam lembaga pendidikan pun menjadi berkurang meskipun banyak dari mereka yang mengetahui bahwa pendidikan anak usia dini yang pertama dan utama terletak pada orangtua.

Oleh karena itu peneliti ingin melakukan penelitian mengenai harapan orangtua terhadap pendidikan keorangtuaan. Peneliti memilih untuk fokus kepada ayah dan ibu yang bekerja serta memiliki anak usia dini (2-6 tahun) saja karena pertumbuhan dan perkembangan anak pada masa ini berlangsung sangat pesat. Penelitian ini dilakukan dengan metode kuantitatif dengan jenis penelitian survei. Kuesioner dalam penelitian ini dibuat dalam bentuk pertanyaan tertutup dan dilengkapi dengan pertanyaan terbuka untuk memperoleh informasi yang perlu diperdalam. Penelitian ini dilakukan di PAUD Al Azhar Pusat dengan populasi penelitian sejumlah 289 orang. Sementara yang diambil sebagai sampel dalam penelitian ini adalah 30 orangtua murid TK Al Azhar Pusat yang terdiri dari Toddler, Play Group, TK A, dan TK B.

Pengolahan data hasil survey yang dilakukan kepada 30 orang responden yang terdiri dari Ibu $(86,7 \%)$, ayah $(6,7 \%)$ dan wali $(6,7 \%)$ ini menggunakan analisis deskriptif. Adapun hasilnya adalah sebagai berikut : 33\% kegiatan Pelatihan yang paling mungkin dilakukan, diskusi kelompok kecil dengan pakar (17\%), dilibatkan sebagai pendamping guru (13\%) dan talkshow (7\%).

Abstract - These days parents, especially the one who lives in a big city, often faced with big challenges in caring and nurturing their children. The challenges not only about development problem as the children grown up (Carter \& McGoldrick dalam Craig,1986) but also about politics, social and economy which affected the parenting's capabilities become weaken (Evans, Judith L, 2006). Parents, especially who has preschooler children, have strategies to optimizing the parenting's role, one of them is by involving household assistance, baby sitter, or extended family. As the result, these also affected their involvement in children education eventhough most of them have known that parents are children's first and primary caregiver.

Those backgrounds has led us, as researchers, to do a research about Parents's Hope in Parenting's education. Research target are dual worker spouse who has children about 2-6 years old. Researcher choose the early childhood stage because on this stage chidren has a spurt growth and development. This survey research, is a quantitative research, which has closed questions and complimentary with open question to get deeper information The survey questions asked the parents to

\footnotetext{
${ }^{1}$ Paper ini telah di Seminarkan di Seminar Nasional Pendidikan AUD SPS Universitas Pendidikan Indonesia Bandung pada 8-9 Mei 2015
} 
choose what kind of topics and forms of parenting program that they hope to be held in the earlychildhood institution. The research took place in centre Al Azhar which has total population 289 people.

Data processing of this survey is descriptive analysis and has involved 30 parents from kindergarten, toddler, and playgroup in centre Al Azhar which consist of mothers (86,7\%), fathers $(6,7 \%)$ and others $(6,7 \%)$ as the respondents. The findings shown that $33 \%$ of the parents are hoping for training activity, $17 \%$ hoping for small discussion group with experts, $13 \%$ hoping for collaboration with teacher's role, and $7 \%$ hoping to have a talkshow.

Keywords: Parents hope, parenting early childhood children, early childhood education

\section{PENDAHULUAN}

\section{Latar Belakang Masalah}

Derkembangan zaman dan teknologi yang Pemakin canggih memberikan dampak dan konsekuensi pada berbagai bidang, termasuk dalam hal pendidikan kepada anak. Orang tua masa kini, terutama yang berada di kota besar semakin dihadapkan pada tantangan yang sulit dalam mengasuh dan mendidik buah hati. Orangtua tidak hanya harus menghadapi segala tantangan dan tuntutan yang timbul seiring dengan perkembangan anak dalam setiap siklus kehidupannya (Carter \& McGoldrick dalam Craig,1986), tapi juga harus berjuang dengan kondisi politik, sosial dan ekonomi yang berpotensi besar melemahkan kemampuan mereka untuk memberikan dukungan yang tepat untuk anak-anak (Evans, Judith L, 2006).

Tidak ada pendidikan yang khusus untuk menjadi orang tua. Setiap individu dituntut untuk mencari tahu dan mempelajari sendiri cara-cara yang dapat diterapkan ketika menjalankan peran sebagai orang tua. Nilai-nilai yang diperoleh individu dari orang tua-orang tua sebelumnya tidak semua dapat diterapkan kembali karena perubahan nilai dan norma sosial sebagai dampak perubahan zaman, akibatnya terjadi ketidakpercayaan diri dalam melakukan pengasuhan kepada anak.

Fungsi pengasuhan anak pun menjadi tidak jelas, siapakah yang memberikan pengasuhan untuk anakanak mereka, apakah saudara, asisten rumah tangga, baby sitter atau orangtua mereka sendiri meskipun pendapat umum bahwa pengasuh yang paling utama bagi anak-anak adalah orangtua biologis mereka.

Tidak banyak orangtua biologis yang memiliki cukup waktu untuk menjalankan fungsinya secara penuh sebagai pengasuh utama karena waktu kerja mereka yang panjang demi memenuhi kebutuhan untuk bertahan hidup.
Jika orangtua mengalami masalah ekonomi atau tekanan sosial maka anakpun tidak mendapatkan pengasuhan yang seharusnya ia dapatkan. Misalnya, pada anak di perkotaan yang kedua orangtuanya bekerja. Pada pemenuhan gizi anak, orangtua cenderung menyediakan makanan cepat saji atau menuruti kemauan anak untuk mengkonsumsi menu tertentu saja. Pada permasalahan komunikasi, orangtua memberikan telepon seluler. Pada permasalahan pembelajaran orangtua menyediakan komputer yang dapat mengakses internet untuk membantu anak mengakses informasi yang dibutuhkan atau anak disertakan dalam kursuskursus.

Untuk memberikan kebutuhan anak terhadap hiburan, banyak orang tua yang memilih cara yang instant karena dianggap lebih efisien, salah satunya adalah menyediakan tontonan melalui televisi dengan tayangan-tayangan yang tidak sepenuhnya sesuai dengan nilai-nilai yang dianut. Hal ini mengakibatkan tidak berimbangnya aktivitas anak. Anak kurang mengembangkan keterampilan motorik kasarnya, mata anak lebih banyak terpapar oleh media, anak akrab dengan berbagai macam media sosial sebagai salah satu wadah anak untuk berbagi berbagai macam hal kepada jaringan media sosialnya termasuk kepada orangtuanya, anak lebih mempercayai sumber informasi yang diperoleh dari internet dibandingkan dari guru ataupun orangtuanya, anak kurang dapat memilah mana nilai-nilai karakter yang penting untuk dikembangkan dan diinternalisasikan ke dalam perilakunya sehari-hari dan lain sebagainya.

Fenomena yang mengindikasikan bahwa orangtua kurang dapat mengimbangi kemampuannya dengan perkembangan anak dan perkembangan jaman telah mendapat perhatian dari banyak pihak, baik dari pemerintah, LSM, maupun lembaga swasta. Pemerintah pun sudah menetapkan kebijakan yang menegaskan bahwa penyelenggaraan pendidikan 
keorangtuaan diakui sebagai pendidikan informal (Undang-undang Republik Indonesia, No. 20 tahun 2003 tentang Sistem Pendidikan Nasional).

Direktorat Pembinaan PAUD Kementerian Pendidikan dan Kebudayaan pun sudah mengimplementasikan Undang-undang Republik Indonesia, No. 20 tahun 2003 tentang Sistem Pendidikan Nasional, dengan membuat program pendidikan anak usia dini berbasis keluarga. Program ini ditujukan kepada para orangtua atau anggota keluarga lain dalam rangka menyelaraskan pengetahuan dan keterampilan untuk melaksanakan perannya dalam peningkatan gizi dan kesahatan, perawatan, pengasuhan, pendidikan dan perindungan di rumah sehingga anak dapat tumbuh dan berkembang secara optimal, sesuai usia dan tahap perkembangannya.

Kebijakan pemerintah tersebut telah mendorong berkembangnya tabloid, website ataupun buku seri praktis yang terkait dengan peningkatan kapasitas diri orangtua. Bahkan, beberapa tahun belakangan ini berkembang pula lembaga-lembaga yang memberikan pelatihan/seminar/workshop untuk memberikan dukungan sosial, pengetahuan, dan keterampilan bagi para orangtua.

Hal ini menunjukkan bahwa orangtua memang dirasakan perlu untuk ditingkatkan kualitasnya sehingga pengetahuan dan keterampilan mereka bertambah dan berkembang dan siap menghadapi berbagai tantangan. Penelitian dan kegiatan seputar program pendidikan keorangtuaan sudah banyak dilakukan untuk meningkatkan keterlibatan orangtua di dalamnya namun masih minim pihak yang meletakkan penelitian sebagai basis untuk pengembangan program pendidikan keorangtuaan.

Oleh karena itu peneliti ingin melakukan penelitian mengenai harapan orangtua terhadap pendidikan keorangtuaan. Peneliti memilih untuk fokus kepada ayah dan ibu yang bekerja serta memiliki anak usia dini (2-6 tahun) saja karena pertumbuhan dan perkembangan anak pada masa ini berlangsung sangat pesat dan peranan orangtua sebagai peletak pondasi dasar kehidupan anak pun memberikan kontribusi terbesar. Disamping itu, pada usia 2-6 tahun anak sudah bisa mengikuti pendidikan di sekolah yang disesuaikan dengan tahap perkembangannya.

\section{Masalah Penelitian}

Adapun masalah dari penelitian ini adalah : Apakah harapan orang tua anak usia dini terhadap pendidikan keorangtuaan?

\section{Tujuan dan Manfaat Penelitian}

Tujuan dari penelitian ini untuk mendapatkan gambaran umum mengenai harapan orang tua yang memiliki anak usia dini terhadap pendidikan keorangtuaan yang dapat meningkatkan kualitas mereka sebagai orangtua dalam upaya pencapaian pertumbuhan dan perkembangan anak yang optimal meskipun mereka bekerja.

Manfaat secara teoritis dari hasil penelitian ini diharapkan menjadi sumber informasi dan pengetahuan baik untuk pendidik, masyarakat, pemerhati pendidikan, penyelenggara pendidikan keorangtuaan dan pemerintah dalam mengembangkan pendidikan keorangtuaan yang tepat guna. Sedangkan manfaat praktis dari penelitian ini adalah sebagai dasar bagi civitas akademika, khususnya di Universitas Al Azhar Indonesia, untuk berpartisipasi aktif di masyarakat, terutama yang terkait dengan pengembangan pendidikan keorangtuaan anak usia dini.

\section{KAJIAN TEORI}

Bab ini membahas istilah-istilah yang digunakan dalam penelitian dan kajian teori yang berkaitan dengan penelitian ini.

\section{Harapan Orangtua}

Mengutip Kamus Besar Bahasa Indonesia, kata harapan berasal dari kata harap yang berarti keinginan supaya sesuatu terjadi. Lebih lanjut Mustopo (1989) menjelaskan bahwa setiap manusia mempunyai harapan dan biasanya harapan tersebut sesuai dengan pengetahuan, pengalaman, lingkungan hidup dan kemampuannya. Harapan ini berperan untuk mengarahkan tingkah laku (Parsons dalam Hollander, 1981).

Menurut Maslow, jika seseorang tidak dapat mewujudkan harapannya maka akan menimbulkan ketidakseimbangan, yang dapat memberikan beban mental pada diri orang tersebut, misalnya: putus asa, selalu termenung, frustasi dan sebagainya. Hal ini dirasakan sebagai sesuatu yang tidak nyaman dan membuat manusia berupaya berbagai macam cara untuk mewujudkan harapannya. Beberapa faktor yang mendasari keputusan manusia adalah faktor lingkungan sosial, ekonomi, pendidikan, landasan iman, rasa percaya diri dan pendidikan mental.

Menurut Eccles (dalam Morgan dkk., 1995) cara orangtua mengoptimalkan perkembangan anak dapat dipengaruhi oleh harapan orangtua terhadap 
kehidupan anaknya kelak. Berarti, bila orangtua mengharapkan anaknya mau bekerja keras dan berjuang meraih kesuksesan, maka anak akan terdorong untuk melakukan dan menghargai perilaku yang diarahkan pada pencapaian prestasi dengan caranya sendiri.

Dengan demikian harapan orangtua dapat diartikan sebagai keinginan terhadap diri pribadi orangtua agar memperoleh pendidikan keorangtuaan yang selaras dengan pencapaian anak yang sukses dalam prestasi, keyakinan beragama dan pemenuhan kebutuhan hidupnya.

\section{Peran Orangtua Anak Usia Dini}

Orangtua adalah pasangan yang telah mendapatkan anak (Duvall dan Miller,1985). Papalia \& Olds (2004) mengungkapkan bahwa masa transisi seseorang menjadi orangtua umumnya berada pada rentang usia dewasa, yaitu dewasa awal (20-40 tahun).

Orangtua harus menghadapi menghadapi segala tantangan dan tuntutan yang timbul seiring dengan perkembangan anak di dalam setiap siklus kehidupan keluarga (Carter \& McGoldrick dalam Craig, 1986). Anak usia dini yang berada pada rentang usia 0-6 tahun berada pada masa prasekolah. Menurut Martin \& Colbert (1997), orangtua anak usia prasekolah berada dalam tahap Authority, dimana orangtua bekerjasama dengan tokoh otoritas lain yang berada dalam lingkungan anak (misalnya guru) berperan dalam membuat aturan, membangun komunikasi dan membuat batasan-batasan perilaku anak yang diinginkan. Pada penelitian ini Anak Usia Dini dibatasi usia 2-6 tahun.

Mengacu pada Permendiknas No. 58 Th. 2009 tentang Standar Pendidikan Anak Usia Dini (PAUD), perkembangan anak usia dini (AUD) mencakup aspek pemahaman nilai-nilai agama dan moral, fisik, kognitif, bahasa, dan sosial-emosional. Tugas pengasuhan selama batita memiliki peranan yang sangat penting untk membangun hubungan antara orang tua dan anak. Orang tua harus dapat menyesuaikan diri dan dapat menerima perubahanperubahab yang ada menjadi orang tua karena dasar cinta kepada anak. Tugas utama orang tua dalam mengasuh anak adalah memberikan kasih sayang kepada sang anak. Yaitu dengan menerima semua kondisi bayi dan harus menerima peran baru mereka sebagai orang tua. Penelitian menunjukan bahwa kondisi bayi dapat berdampak pada begaimana cara dan kemampuan orang tua dalam mengasuh anak mereka; orang tua dari bayi yang dianggap lebih sulit dan menuntut, mengalami perubahan yang negatif dalam hidup mereka. Mereka menganggap bahwa diri mereka sebagai orang tua yang kurang kompeten (Robert, 1983).

Orang tua seharusnya dapat mengatasi perbedaan yang terjadi antara harapan dan kenyataan sebagai orang tua. Tujuannya agar dalam setiap proses pertumbuhan serta perkembangan seorang anak masih terus dalam pengawasan orang tua,dan diharapkan untuk seluruh orang tua agar dalam setiap proses belajar anak selalu diperhatikan agar anak tersebut benar-benar mendapatkan hal-hal baik dalam kehidupannya.

Ibu dan ayah harus memiliki peran yang seimbang serta berbeda alam mengasuk dan mengurus anakanak mereka. Ibu cenderung terlibat dalam kegiatan pengasuhan seperti memberikan makan, mengganti popok dan memandikan anak. Sedangkan ayah cenderung bergerak dibidang kegiatan bermain.

\section{Pendidikan Keorangtuaan}

Beberapa tahun belakangan ini banyak sekali penyelenggaraan program pendidikan keorangtuaan, baik yang dikelola oleh pemerintah, masyarakat, ataupun oleh lembaga swasta dalam bentuk, pelatihan, workshop, seminar, penyuluhan dan lain sebagainya. Program-program tersebut, secara umum memiliki target yang berbeda-beda, ada yang bertujuan untuk meningkatkan satu atau kombinasi dari aspek pengetahuan, keterampilan, sikap, sarana untuk mendapatkan dukungan sosial, ataupun untuk pemberdayaan orangtua (Martin \& Colbert, 1997). Pencapaian tujuan-tujuan tersebut dilakukan dengan berbagai macam cara, pengemasan informasi yang unik dengan alokasi waktu yang berbeda-beda pula karena memang ada banyak cara untuk menjadi orangtua yang sukses membantu tercapainya tumbuh kembang anak yang optimal.

\section{METODE PENELITIAN}

\section{Jenis Penelitian}

Penelitian ini dilakukan dengan metode kuantitatif dengan jenis penelitian survei. Penelitian survei merupakan penelitian yang menggunakan kuesioner sebagai instrumen penelitian. Kuesioner merupakan lembaran yang berisi beberapa pernyataan dengan struktur yang baku (Prasetyo \& Miftahul Jannah, 2005). Kuesioner dalam penelitian ini dibuat dalam bentuk pertanyaan tertutup dan dilengkapi dengan 
pertanyaan terbuka untuk memperoleh informasi yang perlu diperdalam.

\section{Subyek Penelitian}

Populasi penelitian ini adalah seluruh orangtua murid Sekolah Al Azhar Pusat yang terdiri dari 289 orang. Jadi total jumlah populasi penelitian ini adalah 289 orang. Sementara yang diambil sebagai sampel dalam penelitian ini adalah 30 orangtua murid TK Al Azhar Pusat yang terdiri dari Toddler, Play Group, TK A, dan TK B. Penentuan jumah subyek penelitian yang akan digunakan, ditentukan berdasarkan batas minimal yang dikemukakan oleh Guilford \& Fruchter (1978), yaitu tidak kurang dari 30 orang responden.

\section{Teknik Penarikan Sampel}

Teknik penarikan sampel pada penelitian ini adalah non probabilita dengan bentuk insidental sampling karena keterbatasan kesempatan untuk bertemu dengan seluruh orangtua murid, sehingga yang diambil sebagai sample adalah yang kebetulan bisa bertemu dan bersedia menjadi sampel saja.

Oleh sebab itu metode non probabilita adalah metode yang sesuai digunakan karena tidak setiap individu dalam populasi penelitian ini memiliki kesempatan yang sama untuk menjadi subjek penelitian (Kidder \& Judd, 1986). Dengan demikian kesimpulan yang dapat ditarik dari penelitian ini hanya berlaku pada sampel penelitian ini saja (Gulo, 2002).

\footnotetext{
Alat Penelitian

Penelitian ini menggunakan alat penelitian berupa kuesioner. Kuesioner adalah alat pengumpul data yang berupa daftar pertanyaan atau pernyataan tertulis yang dijawab sesuai dengan keadaan menurut subjek. Kuesioner dapat dijawab dengan berbagai cara, antara lain, melalui wawancara tatap muka, diisi sendiri oleh subjek, dijawab melalui telepon, atau pos. Pengisian kuesioner pada penelitian ini diisi sendiri oleh subjek dan dilengkapi dengan wawancara secara langsung dan melalui telepon untuk lebih memperdalam hasil yang diperoleh.

Beberapa kelebihan kuesioner adalah sebagai berikut :
}

1.Nyaman digunakan karena dapat diadministrasikan kepada banyak orang dalam satu waktu.

2. Lebih ekonomis jika dibandingkan dengan wawancara mendalam.

3.Responden merasa lebih aman karena anonimitas pada kuesioner.

Kuesioner dalam penelitian ini adalah kuesioner mengenai "Harapan Orangtua Anak Usia Dini terhadap Pendidikan Keorangtuaan".

\section{Teknik Pengolahan Data}

Pengolahan data dalam penelitian ini menggunakan analisis deskriptif, yaitu analisis yang menekankan pada pembahasan data-data dan subjek penelitian dengan menyajikan data-data secara sistematik dan tidak menyimpulkan hasil penelitian (Priyatno, 2008). Satistik deskriptif menggambarkan tentang ringkasan data-data penelitian seperti mean, standar deviasi, varian, modus, dan lain-lain.

\section{Prosedur Penelitian}

Secara garis besar penelitian ini dilakukan dalam 3 tahapan, yaitu:

\section{a. Persiapan penelitian}

Hal-hal yang perlu dipersiapkan untuk penelitian ini adalah membuat alat ukur berupa kuesioner. Hal lain yang perlu dipersiapkan adalah menghubungi pihak-pihak yang terkait dan dibutuhkan sebagai subjek dalam penelitian ini, termasuk surat izin kepada Sekolah Al Azhar Pusat untuk melakukan penelitian.

b. Pelaksanaan penelitian

Pelaksanaan penelitian ini dilaksanakan pada bulan November 2013 sampai bulan April 2014.di Jakarta.

c. Pelaporan

Pada tahap ini peneliti melakukan pengolahan data penelitian yang sudah terkumpul dengan menggunakan program SPSS (Statistical Product and Service Solution). Berdasarkan hasil pengolahan dan analisis data tersebut, maka peneliti dapat membuat laporan penelitian secara lengkap dari awal sampai akhirnya menemukan jawaban masalah penelitian. 


\section{HASIL DAN PEMBAHASAN}

\section{Gambaran Umum Responden}

Jumlah keseluruhan responden survei ini adalah 31 orang. Namun data yang bisa diolah adalah 30 orang yang merupakan sampel yang dipilih secara accidental sampling, dikarenakan ada data yang kurang lengkap terisi. Secara lebih rinci gambaran responden dari survei ini adalah sebagai berikut :

\section{Karakteristik Responden}

Gambaran responden berdasarkan usia dapat diperoleh hasil bahwa responden terbanyak adalah pada rentang usia 31 - 40 tahun $(56,7 \%)$, diikuti oleh responden berusia kurang dari sama dengan 30 tahun $(23,3 \%), 41$ - 50 tahun (16,7\%) dan lebih dari 50 tahun $(3,3 \%)$. Responden didominasi oleh para Ibu $(86,7 \%)$, selain para Ibu juga ada berhubungan sebagau Ayah dan Wali dari anak yang bersekolah di PAUD (TPA/KB/TK), masingmasing sebesar 6,7\%. Sebagian besar dari responden, berpendidikan terakhir Perguruan Tinggi $(36,7 \%)$, diikuti dengan Akademi/Pernah Kuliah (30\%) dan SMA/sederajat (30\%), dan masih ada yang berpendidikan SMP (3,3\%). Bidang pekerjaan responden cukup bervariasi, sehingga sebagian besar (50\%) dikelompokkan dalam pekerjaan Lain-lain (meliputi: Ibu Rumah Tangga, Dosen Guru, dsb.), sebagian lainnya bekerja sebagai Pegawai Swasta (16,7\%), Pengusaha/Wiraswasta (10\%), Pegawai Negeri $(6,7 \%)$, serta Tidak Bekerja (13,3\%).

\section{Karakteristik Anak Responden}

Gambaran anak dari responden menunjukkan sebagian besar berusia kurang dari sama dengan 4 tahun $(46,7 \%)$, diikuti usia $4-5$ tahun $(30 \%), 5-6$ tahun $(16,7 \%)$ dan lebih dari 6 tahun $(6,7 \%)$. Sesuai dengan gambaran usia anak-anak tersebut, kelompok belajar yang mereka ikuti sebagian besar adalah kelompok A (46,7\%), dan sebagaian kelompok B (36,7\%). Berdasarkan Jenis Kelamin, sebagian besar anak berjenis kelamin Perempuan $(63,3 \%)$, diikuti dengan Laki-laki (36,7\%). Sebagian besar dari mereka (53,3\%) merupakan anak pertama dari orangtua masing-masing.

\section{Karakteristik Sekolah dari Anak Responden}

Gambaran lembaga tempat anak dari responden bersekolah mengenai uang pendaftaran di berbagai lembaga tersebut bervariasi mulai dari kurang dari sama dengan Rp. 1 juta (20\%), Rp. 1 juta - Rp. 5 juta (20\%), Rp. 5 juta - Rp. 10 juta (10\%), dan lebih dari Rp. 10 juta (20\%). Sedangkan untuk uang SPP lembaga-lembaga tersebut, sebagian besar kurang dari Rp. 250 ribu (30\%), diikuti dengan Rp. 500 ribu - Rp. 1 juta (16,7\%), Rp. 250 ribu - Rp. 500 ribu (13,3\%) dan lebih dari Rp. 1 juta (10\%). Dari sejumlah lembaga tersebut, mereka memiliki program-program yang melibatkan orangtua, sebagian besar responden pernah dilibatkan dalam kegiatan Seminar (26,7\%), Market Day (10\%) dan program lainnya $(16,7 \%)$.

\section{Harapan Responden terhadap Pendidikan Keorangtuaan di Lembaga PAUD (TPA/KB/TK)}

Dalam survei ini, responden diminta untuk menyampaikan harapan mereka terhadap pendidikan keorangtuaan di Lembaga PAUD (TPA/KB/TK) melalui usulan bentuk-bentuk kegiatan yang mereka inginkan (dianggap paling sesuai), berdasarkan 9 (sembilan) topik atau tujuan program kegiatan orangtua yang disajikan. Harapan orangtua terhadap bentuk kegiatan yang menurut mereka paling sesuai untuk setiap kegiatan tersebut sebagai berikut:

\section{Program yang Bertujuan Mengembangkan Pemahaman Orangtua tentang Pertumbuhan dan Perkembangan Anak}

Pada umumnya (33\%), orangtua mengharapkan Lembaga PAUD (TPA/KB/TK) dapat membuat kegiatan berbentuk Pelatihan yang bertujuan mengembangkan pemahaman orangtua tentang pertumbuhan dan perkembangan anak, sebagian besar orangtua lainnya (30\%) mengharapkan kegiatan tersebut dibuat dalam bentuk Seminar, diikuti dengan Diskusi kelompok kecil (kurang dari 10 orang) dengan melibatkan pakar (20\%), dilibatkan sebagai Pendamping guru di dalam dan di luar kelas (10\%) dan Talkshow (7\%).

\section{Program yang Bertujuan Mengembangkan Rasa Percaya Diri Orangtua dalam Mengasuh Anak}

Pada umumnya (40\%), orangtua mengharapkan Lembaga PAUD (TPA/KB/TK) dapat membuat kegiatan berbentuk Pelatihan yang bertujuan mengembangkan rasa percaya diri orangtua dalam mengasuh anak, sebagian besar orangtua lainnya (27\%) mengharapkan kegiatan tersebut dibuat dalam bentuk Seminar, diikuti dengan Diskusi kelompok kecil (kurang dari 10 orang) dengan melibatkan pakar (23\%), dilibatkan sebagai Pendamping guru di dalam dan di luar kelas $(7 \%)$ dan Talkshow (3\%). 
Program yang Bertujuan Mempelajari tentang Pengalaman Anak-Anak Mereka selama Melakukan Kegiatan di Lembaga

Pada umumnya (36\%), orangtuaingin dilibatkan sebagai Pendamping guru di dalam dan di luar kelas agar dapat mempelajari tentang pengalaman anak-anak mereka selama melakukan kegiatan di lembaga. Sebagian besar orangtua lainnya (30\%) mengharapkan kegiatan tersebut dibuat dalam bentuk Diskusi kelompok kecil (kurang dari 10 orang) dengan melibatkan pakar (23\%), diikuti dengan Pelatihan (20\%), serta Seminar dan Talkshow, masing-masing sebesar 7\%.

Program yang Bertujuan Memahami AnakAnak Mereka dengan Mengamati Anak-Anak Lain yang Sebaya

Pada umumnya (40\%), orangtua mengharapkan Lembaga PAUD (TPA/KB/TK) dapat membuat kegiatan berbentuk Pelatihan yang bertujuan memahami anak-anak mereka dengan mengamati anak-anak lain yang sebaya, sebagian besar orangtua lainnya $(33 \%)$ ingin dilibatkan sebagai Pendamping guru di dalam dan di luar kelas, diikuti dengan Diskusi kelompok kecil (kurang dari 10 orang) dengan melibatkan pakar (23\%), dan Seminar (10\%). Tidak ada yang mengusulkan kegiatan dilakukan dalam bentuk Talkshow untuk tujuan tersebut.

Program yang Bertujuan Mempelajari CaraCara Baru tentang Berinteraksi yang Positif dengan Anak-Anak

Pada umumnya (40\%), orangtua mengharapkan Lembaga PAUD (TPA/KB/TK) dapat membuat kegiatan berbentuk Pelatihan yang bertujuan mempelajari cara-cara baru tentang berinteraksi yang positif dengan anak-anak, sebagian besar orangtua lainnya (20\%) mengharapkan kegiatan tersebut dibuat dalam bentuk Seminar, diikuti dengan Diskusi kelompok kecil (kurang dari 10 orang) dengan melibatkan pakar dan dilibatkan sebagai Pendamping guru di dalam dan di luar kelas (masing-masing sebesar 17\%) dan Talkshow $(6 \%)$.

Program yang Bertujuan Mendapatkan Informasi yang Cukup tentang Sumber-Sumber Lain di Masyarakat yang Dapat Meningkatkan Pengetahuan dan Ketrampilan Orangtua

Pada umumnya (37\%), orangtua mengharapkan Lembaga PAUD (TPA/KB/TK) dapat membuat kegiatan berbentuk Pelatihan dan Seminar (masingmasing sebesar $37 \%$ ) yang bertujuan mendapatkan informasi yang cukup tentang sumber-sumber lain di masyarakat yang dapat meningkatkan pengetahuan dan ketrampilan orangtua, diikuti dengan Diskusi kelompok kecil (kurang dari 10 orang) dengan melibatkan pakar (13\%), Talkshow (10\%), dan dilibatkan sebagai Pendamping guru di dalam dan di luar kelas (3\%).

\section{Program yang Bertujuan Mengembangkan Interaksi antara Anak dan Orangtua}

Pada umumnya (37\%), orangtua mengharapkan Lembaga PAUD (TPA/KB/TK) dapat membuat kegiatan berbentuk Pelatihan yang bertujuan mengembangkan interaksi antara anak dan orangtua, sebagian besar orangtua lainnya $(23 \%)$ mengharapkan kegiatan tersebut dibuat dalam bentuk Seminar, diikuti dengan Diskusi kelompok kecil (kurang dari 10 orang) dengan melibatkan pakar (20\%), dilibatkan sebagai Pendamping guru di dalam dan di luar kelas dan Talkshow (masingmasing sebesar 10\%).

\section{Program yang Bertujuan Mempelajari Cara Orangtua Melanjutkan di Rumah Apa yang} Sudah Dipelajari

Pada umumnya (50\%),orangtua mengharapkan Lembaga PAUD (TPA/KB/TK) dapat membuat kegiatan berbentuk Pelatihan yang bertujuan mempelajari cara orangtua melanjutkan di rumah apa yang sudah dipelajari, sebagian besar orangtua lainnya (27\%) ingin dilibatkan sebagai Pendamping guru di dalam dan di luar kelas, diikuti dengan Seminar (13\%), dan Diskusi kelompok kecil (kurang dari 10 orang) dengan melibatkan pakar $(10 \%)$. Tidak ada yang mengusulkan kegiatan dilakukan dalam bentuk Talkshow untuk tujuan tersebut.

\section{Program yang Bertujuan Memahami Bagaimana Kerjasama Sekolah dan Keluarga/Orangtua dapat Meningkatkan Perkembangan Anak}

Pada umumnya (40\%), orangtua mengharapkan Lembaga PAUD (TPA/KB/TK) dapat membuat kegiatan berbentuk Pelatihan yang bertujuan memahami bagaimana kerjasama sekolah dan keluarga/orangtua dapat meningkatkan perkembangan anak, sebagian besar orangtua lainnya (33\%) ingin dilibatkan sebagai Pendamping guru di dalam dan di luar kelas, diikuti dengan Diskusi kelompok kecil (kurang dari 10 orang) dengan melibatkan pakar (23\%), dan Seminar (10\%). Tidak ada yang mengusulkan kegiatan dilakukan dalam bentuk Talkshow untuk tujuan tersebut. 


\section{Bentuk Kegiatan yang Paling Mungkin Diikuti oleh Orangtua}

Berdasarkan hasil survei (Gambar 1), dapat diketahui bahwa sebagian besar orangtua (33\%) menyatakan kegiatan berbentuk Pelatihan yang paling mungkin diikuti. Sebagian besar lainnya memilih kegiatan berbentuk Seminar (30\%), diikuti dengan Diskusi kelompok kecil dengan Pakar (17\%), dilibatkan sebagai Pendamping Guru (13\%) dan Talkshow (7\%).

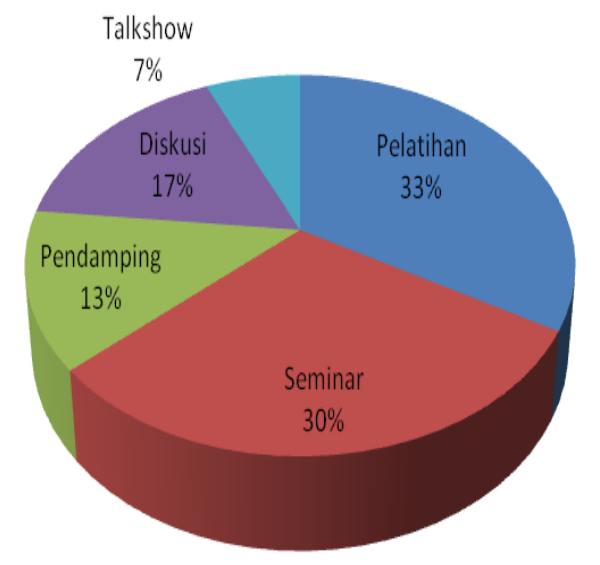

Gambar 1. Bentuk Kegiatan yang Paling Mungkin Diikuti oleh Orangtua

Adapun alasan pemelihan bentuk kegiatan tersebut sebagian besar karena kegiatan tersebut dianggap dapat memberikan informasi yang bermanfaat $(26,7 \%)$, sebagian lainnya beralasan bentuk-bentuk kegiatan tersebut dapat diimplementasikan dan dapat tukar pikiran dengan pakar (masing-masing $16,7 \%$ ), diikuti dengan waktu yang singkat $(13,3 \%)$, orangtua dapat lebih memahami anak (10\%), dan alasan lain (10\%). Alasan-alasan tersebut disajikan pada Gambar 4.14 berikut.

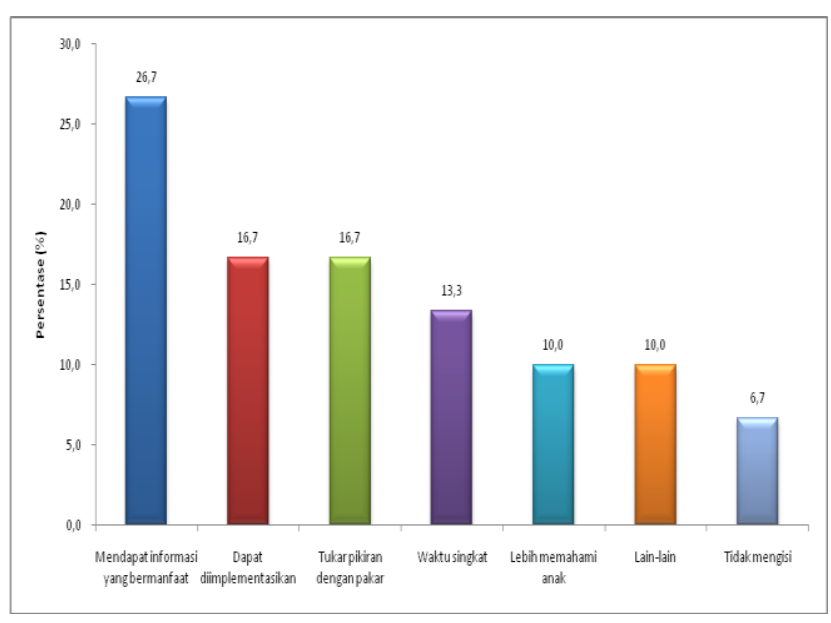

Gambar 2. Alasan Orangtua Memilih Kegiatan yang Paling Sesuai dengan Mereka

\section{Kegiatan yang Paling Dibutuhkan Saat Ini}

Berdasarkan Gambar 2, dapat diketahui bahwa sebagian besar orangtua $(23,3 \%)$ menyatakan bahwa kegiatan yang bertujuan Mempelajari Cara-Cara Baru tentang Berinteraksi yang Positif dengan Anak-Anak merupakan yang paling mereka butuhkan saat ini, tidak sedikit pula (20\%) yang merasa membutuhkan kegiatan yang bertujuan Mempelajari Cara Orangtua Melanjutkan di Rumah Apa yang Sudah Dipelajari. Sebagian lainnya, merasa membutuhkan kegiatan yang bertujuan Mengembangkan Pemahaman Orangtua tentang Pertumbuhan dan Perkembangan Anak, Mendapatkan Informasi yang Cukup tentang Sumber-Sumber Lain di Masyarakat yang Dapat Meningkatkan Pengetahuan dan Ketrampilan Orangtua, dan Mempelajari Cara-Cara Baru tentang Berinteraksi yang Positif dengan Anak-Anak (masing-masing 10\%), serta Mempelajari Cara Orangtua Melanjutkan di Rumah Apa yang Sudah Dipelajari (6,7\%) dan Memahami Anak-Anak Mereka dengan Mengamati Anak-Anak Lain yang Sebaya $(3,3 \%)$. Tidak ada yang memilih kegiatan dengan tujuan Mengembangkan Rasa Percaya Diri Orangtua dalam Mengasuh Anak dan Mempelajari tentang Pengalaman Anak-Anak Mereka selama Melakukan Kegiatan di Lembaga.

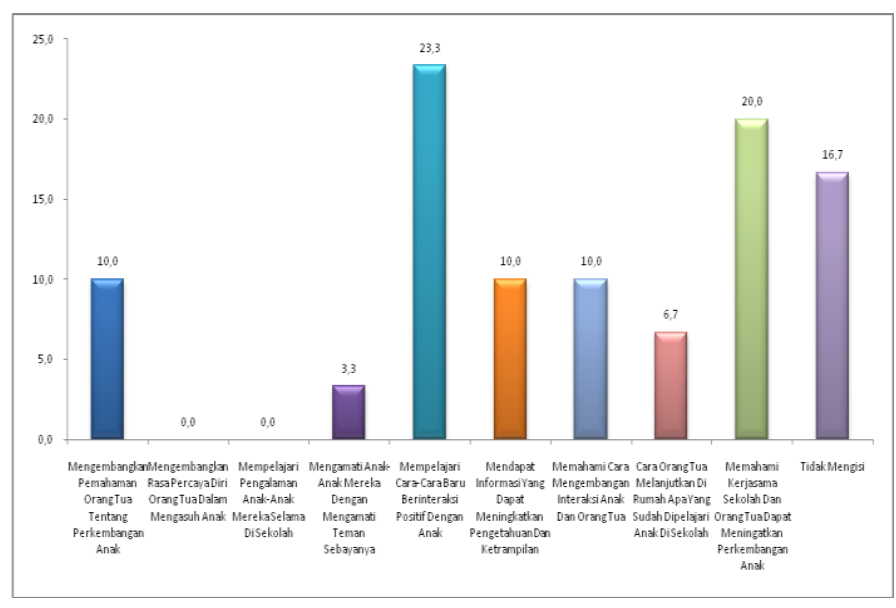

Gambar 3. Kegiatan yang Paling Dibutuhkan Orangtua Saat Ini

\section{KESIMPULAN DAN SARAN}

\section{Kesimpulan}

Dari hasil survey yang sudah dilakukan kepada 30 orang responden yang terdiri dari Ibu $(86,7 \%)$, ayah $(6,7 \%)$ dan wali $(6,7 \%)$, diperoleh hasil sebagai berikut: 
1. Sebagian besar orangtua (33\%) menyatakan bahwa kegiatan berbentuk Pelatihan yang paling mungkin mereka ikuti. Sebagian besar lainnya memilih kegiatan berbentuk seminar $(30 \%)$, diikuti melalui diskusi kelompok kecil dengan pakar (17\%), dilibatkan sebagai pendamping guru (13\%) dan talkshow (7\%). Adapun alasan pemilihan bentuk kegiatan tersebut sebagian besar karena kegiatan tersebut dianggap dapat memberikan informasi yang bermanfaat $(26,7 \%)$, sebagian lainnya beralasan bentukbentuk kegiatan tersebut dapat diimplementasikan dan dapat tukar pikiran dengan pakar (masing-masing 16,7\%), diikuti dengan waktu yang singkat $(13,3 \%)$, orangtua dapat lebih memahami anak (10\%), dan alasan lain (10\%).

2. Sebagian besar orangtua (23,3\%) menyatakan bahwa kegiatan yang bertujuan mempelajari cara-cara baru tentang berinteraksi yang positif dengan anak-anak merupakan hal yang paling mereka butuhkan saat ini, tidak sedikit pula (20\%) yang merasa membutuhkan kegiatan yang bertujuan mempelajari cara orangtua melanjutkan di rumah apa yang sudah dipelajari anak di sekolah. Sebagian lainnya, merasa membutuhkan kegiatan yang bertujuan mengembangkan pemahaman orangtua tentang pertumbuhan dan perkembangan anak, mendapatkan informasi yang cukup tentang sumber-sumber lain di masyarakat yang dapat meningkatkan pengetahuan dan keterampilan orangtua, dan mempelajari cara-cara baru tentang berinteraksi yang positif dengan anak-anak (masing-masing 10\%), serta mempelajari cara orangtua melanjutkan di rumah apa yang sudah dipelajari $(6,7 \%)$ dan memahami anak-anak mereka dengan mengamati anakanak lain yang sebaya $(3,3 \%)$. Tidak ada yang memilih kegiatan dengan tujuan mengembangkan rasa percaya diri orangtua dalam mengasuh anak dan mempelajari tentang pengalaman anak-anak mereka selama melakukan kegiatan di lembaga.

Secara keseluruhan disimpulkan bahwa harapan orangtua terhadap pendidikan keorangtuaan yang dominan adalah mempelajari mengenai cara-cara baru tentang berinteraksi yang positif dengan anakanak mereka, serta mempelajari cara orangtua melanjutkan di rumah apa yang sudah dipelajari anak di sekolah. Orangtua mengahrapkan kegiatan tersebut dilakukan dalam bentuk Pelatihan dan Seminar karena paling mungkin untuk diikuti.

\section{Saran \\ Lembaga PAUD}

Sebaiknya lembaga PAUD merencanakan kegiatan pembelajaran dan menyediakan kegiatan-kegiatan yang berbentuk pelatihan, yang dapat menunjang pemahaman dan meningkatkan keterampilan orangtua dalam mengamati anak-anak. Dengan demikian diharapkan para orangtua dapat lebih peka dan memahami perkembangan anak-anaknya.

\section{Orangtua}

Orangtua dapat berinteraksi secara positif kepada anak-anak dan mengoptimalkan potensi mereka setelah mengikuti kegiatan-kegiatan yang berbentuk pelatihan dan seminar.

\section{Penyelenggara PAUD}

Penyelenggara PAUD sebaiknya membuat program kegiatan pelatihan dan seminar untuk orangtua yang bertujuan untuk memahami dan mengamati anak-anak yang sesuai dengan kebutuhan dan harapan mereka.

\section{DAFTAR PUSTAKA}

[1] Christenson, S.L., Rounds, T. \& Gorney, D. 1992. Family Factors and Student achievement: An Avenue to Increase Student's Success. School Psychology Quarterly, 7 (3): 178-206.

[2] Craig, G.J. 1986. Human Development. $\left(4^{\text {th }}\right.$ edition). New Jersey: Prentice Hall,Inc

[3] Duvall,E.M. \& Miller,B.C. 1985. Marriage and Family Development. (6 $6^{\text {th }}$ edition). New York: Harper \& Row Publishers

[4] Direktorat Pembinaan PAUD. 2011. Pedoman Penyelenggaraan Pendidikan Anak Usia Dini Berbasis Keluarga. Kementerian Pendidikan dan Kebudayaan. Jakarta.

[5] Guilford, J. P., and Fruchter, Benjamin. 1978. Foundamental Statistics in Psychology and Education $6^{\text {th }}$ edition. Singapore: McGrawHill.

[6] Gulo, W. 2002. Metodologi Penelitian. Jakarta: Grasindo.

[7] Hollander, E.P.1981. Principles and Methods of Social Psychology. ( $7^{\text {th }}$ edition). New York: Oxford University 
[8] Kerlinger, Fred. N.2000. Asas-asas Penelitian Behavioral. Yogyakarta: Gadjah Mada University Press.

[9] Kementerian Pendidikan dan Kebudayaan. 2009. Peraturan Menteri Pendidikan Nasional No. 58 tahun 2009 tentang Standar PAUD. Jakarta

[10] Kidder, L. H. \& Judd, C. M. 1989. Research Methods in Social Relation. $5^{\text {th }}$ edition. New York: CBS College.

[11] Martin, Carole. E \& Karen E Colbert. 1997, Parenting: A life Span Perspective. United States of America. Mc Graw Hill.
[12] Mustopo, M.Habib.1989. Ilmu Budaya Dasar. Surabaya: Usaha Nasional

[13] Prasetyo, Bambang., \& Jannah, Lina Miftahul. 2005. Teori dan Aplikasi Metode Penelitian Kuantitatif. Jakarta: PT. Raja Grafindo Persada.

[14] Priyatno, Dwi. 2008. Mandiri Belajar SPSS untuk Analisis Data dan Uji Statistik. Yogyakarta: MediaKom.

[15] Kementerian Pendidikan dan Kebudayaan. 2003. Undang-undang Republik Indonesia, No. 20 tahun 2003 tentang Sistem Pendidikan Nasional. Jakarta. 